\title{
RESULTS OF EXPERIMENTAL TESTING OF HEE GIRL STUDENTS' MOTOR SKILLS AT AEROBIC TRAININGS
}

Martinova N. P.

Luhansk Taras Shevchenko National University

\begin{abstract}
Purpose: to analyze dynamic of motor skills' formation in girl students, who practice aerobic by experimental program. Material: in the research 40 girl students participated. Motor skills level was tested with the help of state and additional tests. Results: it was found that for training quickness it is necessary to use rope skipping in mode, corresponding to development of this quality. For training maximal strength it is purposeful to use more complex power exercises in ground part of the complex. Conclusions: implementation of rope skipping means in dance aerobic trainings increases training influence on practically all motor skills. Rope skipping permits to doze and regulate training load. The same under musical accompaniment develop sense of rhythm. In some modes such jumps facilitate training of speed power qualities and power endurance.
\end{abstract}

Key words: motor skills, aerobic, rope skipping, methodic, girl students, education.

\section{Introduction}

Training and perfection of students' motor skills in HEE is one of important and necessary component of discipline "Physical education". But recent years there have been observed weakening of students' motor skills, especially in girls $[19,21,22]$.

Health related aerobic is a part of girl students' physical education practically in all HEEs. Interest to aerobics is conditioned by its high effectiveness, accessibility, bright emotional character and attractiveness [3, 20, 23].

Modern specialists worked out different approaches to development of motor skills at health related aerobic trainings. Methodic of motor skills' training on the base of graphic analytic models and bio-mechanical motor skills' indicators has been implemented [13]. Module technology of motor coordination training has also been implemented [16], and it permits to individualize training process on the base of girl students' potentials. Effectiveness of rhythm qualities simulation of girl students, who train health related aerobic has been experimentally substantiated [4].

Application of attractive kinds of training, considering girl students' individual features, is of the same importance for physical qualities' training $[6-8,10]$. Specialists recommend not to limited to only one kind of aerobic. It is possible to vary them periodically [5]. Our attention was attracted by rope skipping aerobic. Specialists say that rope skipping is one of the best trainings by covering of muscular system and by its variety [9, 17]. The first rope skipping program was worked out by K. Cooper [5]. N.M. Amosov and I.V. Muravov think that it can not ensure versatile training of youth [1]. Analysis of scientific-methodic literature witnesses about absence of reliable aerobic rope skipping methodic for training of HEE girl students' motor skills. In this aspect the urgency of the topic of our research is rather evident.

Purpose, tasks of the work, material and methods

The purpose of the article is to analyze dynamic of motor skills' formation in girl students, who practice aerobic by experimental program and prove effectiveness of this program.

The methods and organization of the research: the research was conducted on the base of East-Ukrainian National university, named after Vladimir Dal. In experiment 40 girl students, who practice health related aerobic, participated. They were divided into two groups: experimental (EG) - 20 girls and control (CG) - 20 girls. CG girl students were trained by traditional program; EG girl students - by experimental methodic.

Level of motor skills was tested with state tests, envisaged by academic program for discipline "Physical education in HEE" and with additional tests.

Results of the researches

For training of girl students' motor skills at aerobic classes we offered experimental methodic. In dance aerobic program we introduced rope skipping. Such approach stipulates strengthening of aerobic influence on girl students' motor skills. For the period of experiment in both groups we registered confident improvement of results by all tested indicators (see table 1).

At the end of experiment we registered confident improvement of test results "2000meters' run" in EG - 11.03 $\pm 0.62 \mathrm{~min}(\mathrm{p}<0.001)$. It was $8.24 \%$ of increment in comparison with initial indicators. In CG we did not register any significant changes $-11.77 \pm 0.52 \mathrm{~min}(\mathrm{p}<0.001)$, increment was $1.92 \%$. Analysis of test "Long jump from the spot" showed significant difference in final CG indicators $(1.69 \pm 0.07 \mathrm{~m})$ and in EG $(1,77 \pm 0,11 \mathrm{~m})$ at level $\mathrm{p}<0.05$. Increment of CG results was $0.01 \mathrm{~m}(\mathrm{p}<0.001)$, and in $\mathrm{EG}-0.11 \mathrm{~m}(\mathrm{p}<0.001)$. Increment of results in test "High jump from the spot" was in EG $-12.74 \%$ and in CG there were no significant changes $(2.48 \%)$. Final result was, accordingly, the following: $38.05 \pm 2.11 \mathrm{~cm}(\mathrm{p}<0.001)$ and $35.10 \pm 2.20 \mathrm{~cm}(\mathrm{p}<0.001)$.

As we can see, in test "Torso risings in sitting position from lying position during 1 minute) confident increment of results was in both groups $(\mathrm{p}<0.001)$. But in EG rate of increment was higher $-21.61 \%$. It was very good result. In CG increment rate was only $4.31 \%$. In test " 100 meters' run" there were significant differences $(p<0.001)$ in both groups $(E G-17.09 \pm 0.59$ (2.57\%), CG $-17.30 \pm 0.67$ (1.31\%). Differences between final values between two groups were not significant $(\mathrm{p}>0.05)$. In test "Shuttle run $4 \times 9 \mathrm{~m}$ " we registered significant increment of indicators in EG $-6 \%$. At the end of experiment result was $10.81 \pm 0.35 \mathrm{sec} .(\mathrm{p}<0.001)$. Control group indicators nearly did not change: $0.26 \%, 11.40 \pm$

Martinova N. P., 2015

http://dx.doi.org/10.15561/20755279.2015.0507 
0.48 sec. $(p<0.001)$. Increment of test "Pressing ups from the floor" did not have significant differences $(p>0.05)$ between EG $(18.20 \pm 7.06)$ and CG $(15.55 \pm 7.07)$. In test "Forward torso bending in sitting position" we registered confident changes in $\mathrm{EG}-18.50 \pm 3.79 \mathrm{~cm}, \mathrm{CG}-15.60 \pm 4.65 \mathrm{~cm}(\mathrm{p}<0.05)$. Increment rates were accordingly: $\mathrm{EG}-$ $31.21 \%, \mathrm{CG}-12.23 \%$.

2).

To receive more information about effectiveness of experimental methodic we used additional tests (see table

Changes in test "Rope skipping during $30 \mathrm{sec}$." were confident in every group and between groups (p<0.001). At the end of experiment in EG $(73.35 \pm 3.56)$ there was much better result than CG $59.45 \pm 6.92)$. Percentage of increment rates was in EG $-34.71 \%$ and in $-7.6 \%$. Analysis of "Romberg's test" showed that EG girl students' balance indicators increased up to $13.35 \pm 3.07(\mathrm{p}<0.001)$. In $\mathrm{CG}$ they increased only to $6.45 \pm 2.54(\mathrm{p}<0.001)$. The registered differences were statistically confident at level $\mathrm{p}<0,001$.

Test "Integral coordination indicators" (ICI) [2] showed significant difference between results of both groups at level $\mathrm{p}<0.001$. Increment rate of ICI in EG was $84.32 \%$. It witnesses about high level of jump coordination $(0.72 \pm 0.09$, $\mathrm{p}<0.001)$. CG girl students improved their results by $15 \%(0.46 \pm 0.07, \mathrm{p}<0.001)$. We observed confident positive changes in rhythm of basic steps [7] ( $\mathrm{p}<0.001)$. In EG improvement of results was by $35.27 \%(14.00 \pm 0.92$ points $)$, in $\mathrm{CG}$ - by $19.25 \%$ (12.7 \pm 1.08 points). Differences between groups also were of significance $\mathrm{p}<0.001$. Increment rates of jump rhythm in EG were $40.3 \%(4.70 \pm 0.47$ points), and in $C G-20 \%(4.20 \pm 0.52$ points) ( $p<0.001)$. The detected differences between EG and CG girl students in tapping test were statistically different at level $\mathrm{p}<0,01$ (right hand) and $\mathrm{p}<0.05$ (left hand). For example in EG increment rates were: right hand $-8.45 \%(214.25 \pm 11.03$ quantity of points), left hand $-5.88 \%$ (198.00 \pm 10.73 quantity of points). In CG they were accordingly $3.04 \%$ (203.157 \pm 7.08 quantity of points) and $2.36 \%(191.00 \pm 6.27$ quantity of points $)$.

\section{Discussion}

The conducted by us research expands the data about development of HEE girl students' motor skills. The research confirms the conclusions of specialists that aerobics permit to vary methodic depending on its purpose [15]. Application of various aerobic programs permits to obtain maximal use for minimal time [5].

In process of our work on the set problem we worked out and experimentally tested application of rope skipping in dance aerobic.

Analysis of scientific methodic literature witnesses that rope skipping permits to doze and regulate training load. As it is noted by scientists rope skipping is a men of training of general endurance [18]. Rope skipping under music accompaniment develops rhythm sense [14]. In certain modes of load they facilitate training of speed power and power endurance $[11,12]$.

Results of our research confirm it.

\section{Conclusions}

Thus, the received data witness about effectiveness of rope skipping implementation in dance aerobic trainings. Such approach increases training influence on practically all motor skills. For training quickness (in our opinion) it is necessary to use specialized exercises from light athletic or use rope skipping in mode, corresponding to development of this quality. We think to be purposeful to use more complex power exercises in ground part of the complex for development of maximal strength.

\section{Acknowledgement}

The research was conducted in compliance with scientific researches of department of physical education theory and methodic of Luhansk Taras Shevchenko National University - "Theory and methodic of senior pupils' profile training in sport directions in conditions of continuous education" (state registration number 108U002431).

\section{Conflict of interests}

The author declares that there is no conflict of interests. 


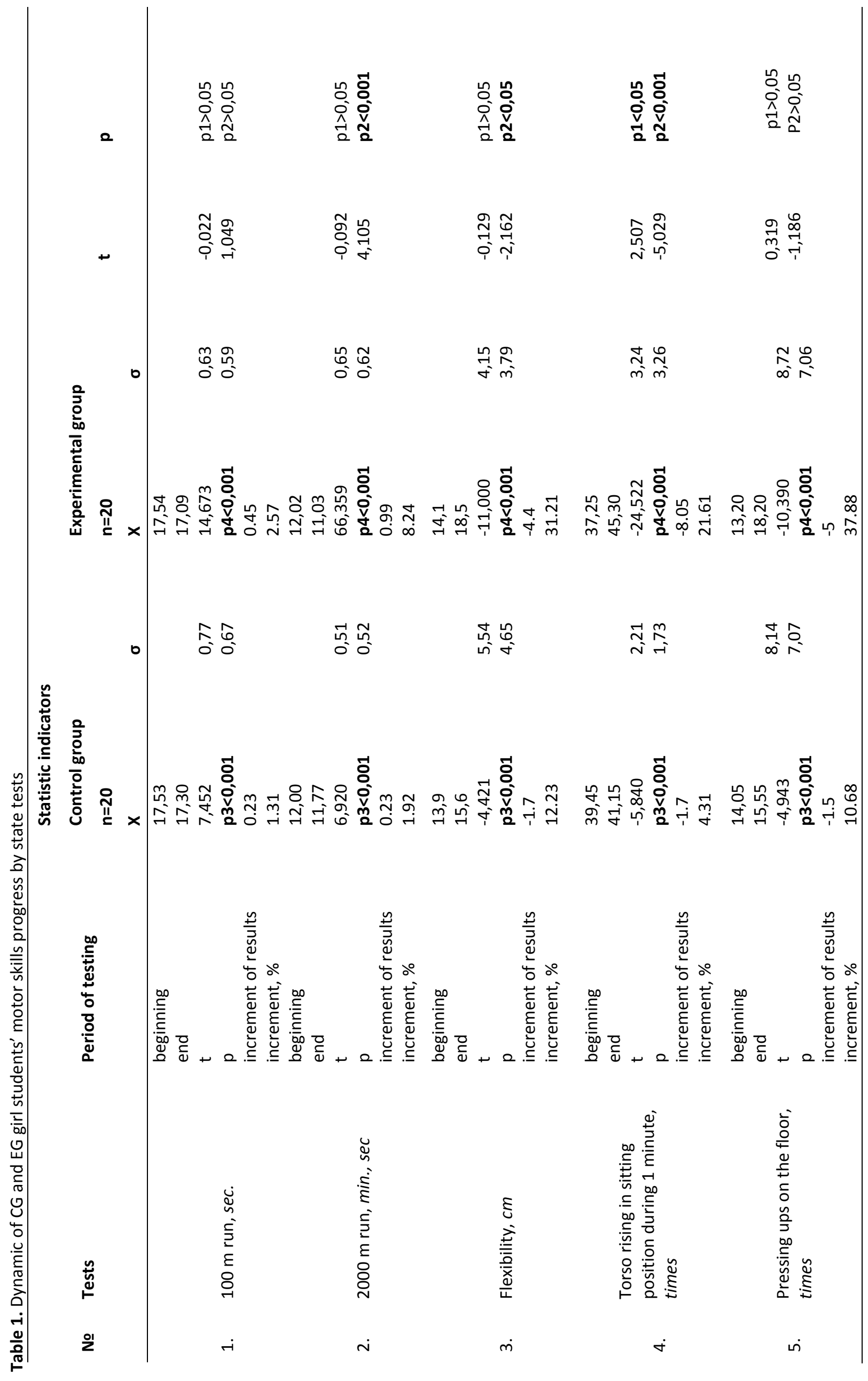




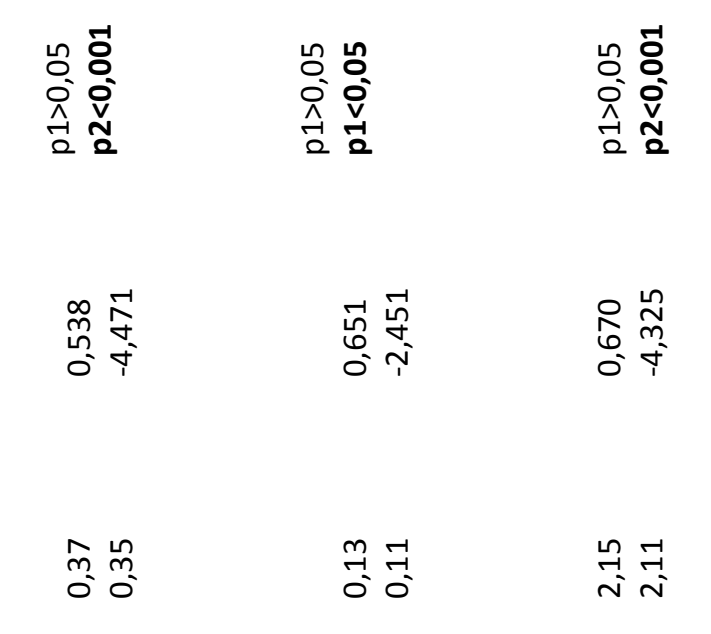

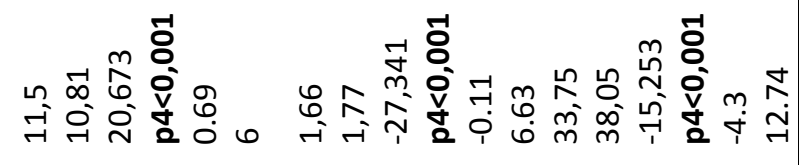
응옹
8
ํํำ ำ

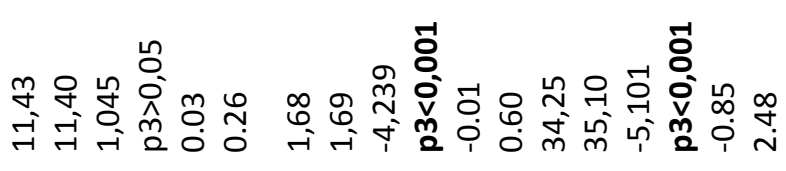

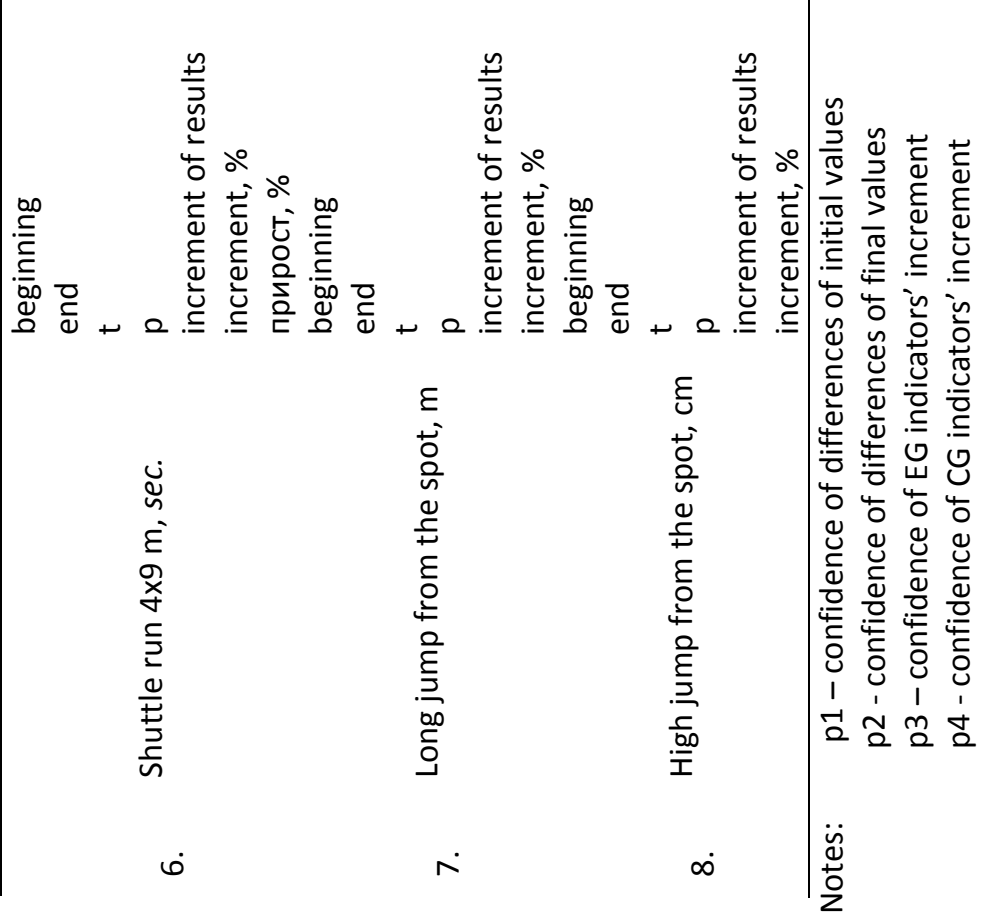




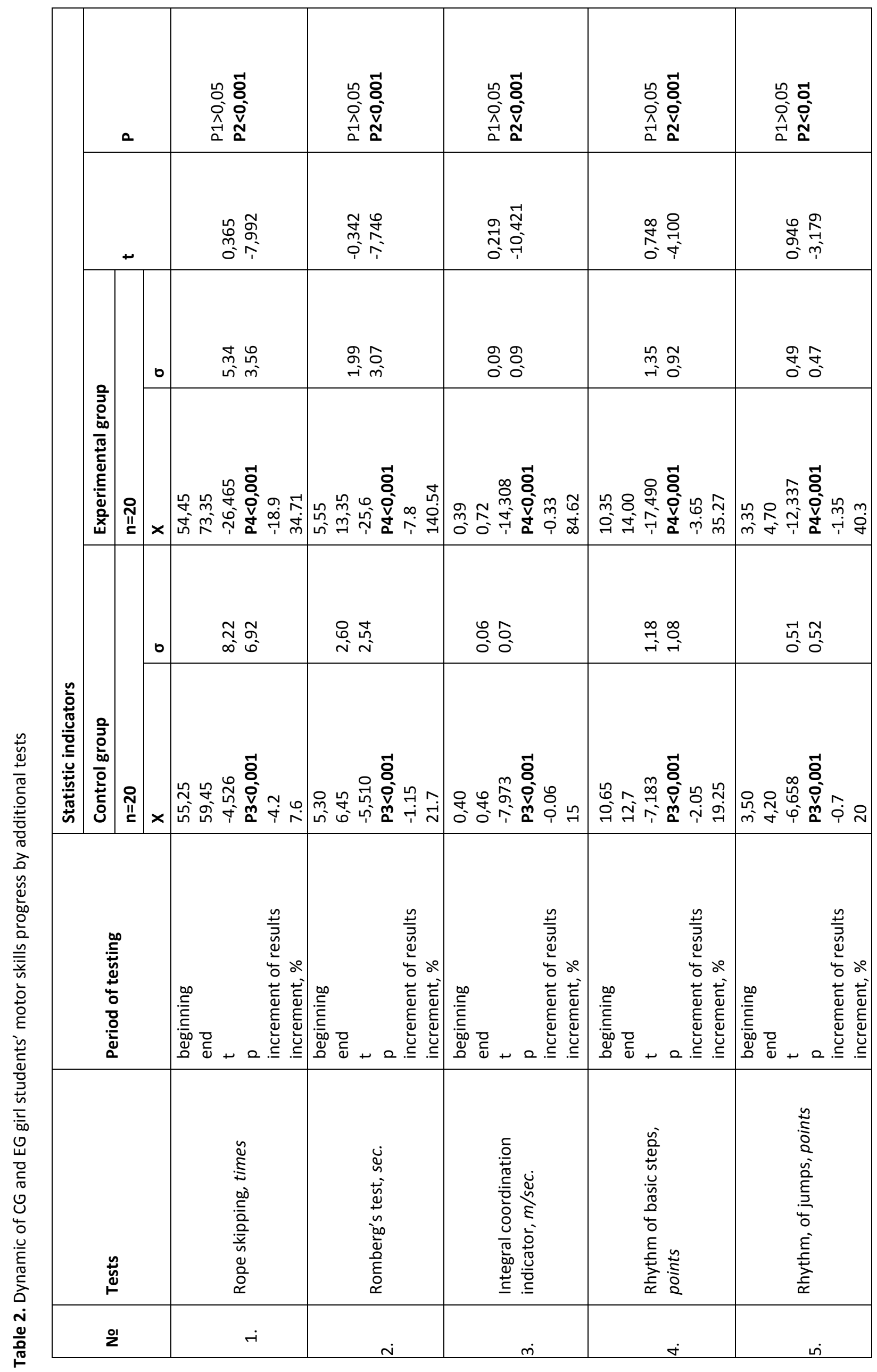




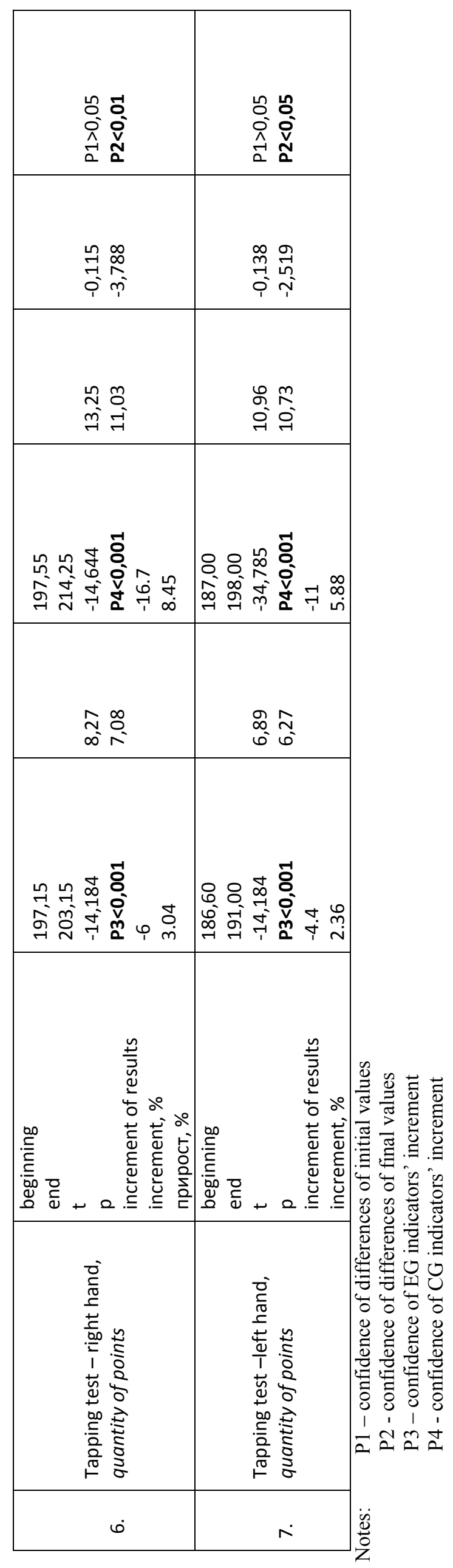




\section{References}

1. Amosov NM, Muravov IV. Serdce i fizicheskie uprazhneniia [Heart and physical exercises], Kiev, Health; 1985. (in Ukrainian)

2. Bulkin VA, Popova EV, Saburova EV. Test dlia ocenki ballisticheskoj koordinacii dvigatel'noj deiatel'nosti [Test for assessment of ballistic coordination of motor functioning]. Teoriia i praktika fizicheskoj kul'tury, 1997;3:4446. (in Russian)

3. Duliba OB. Ocenka i optimizaciia umstvennoj i fizicheskoj rabotosposobnosti studentok sredstvami ritmicheskoj gimnastiki. Cand. Diss. [Assessment and optimization of student's mental and physical workability by means of rhythmic gymnastic. Cand. Diss.], Lviv; 2000. (in Ukrainian)

4. Kostiunina LI. Modelirovanie processa razvitiia ritmichnosti dvizhenij u studentok zanimaiushchikhsia ozdorovitel'noj aerobikoj. Cand. Diss. [Simulation of rhythm training of students, who practice health related aerobics. Cand. Diss.], Ulyanovsk, 2006 (in Russian)

5. Kuper K. Aerobika dlia khoroshego samochuvstviia [Aerobics for good self-feeling],; 1989. (in Russian)

6. Martinova NP. Morfofunkcional'ni osoblivosti zhinochogo organizmu, shcho vplivaiut' na rozvitok rukhovikh iakostej [Morphological-functional characteristics of woman's organism, which influence on development of motor skills]. Moloda sportivna nauka Ukraini, 2014;18(3):128 - 132. (in Ukrainian)

7. Martinova NP. Novi vidi aerobiki, iak zasib rozvitku rukhovikh iakostej studentok VNZ [New kinds of aerobics as mean of HEE girl students' motor skills' training]. Slobozhans'kij naukovo-sportivnij visnik, 2014;1(39):62 65. (in Ukrainian)

8. Martinova NP. Viznachennia motiviv ta interesiv studentok VNZ do zaniat' $\mathrm{z}$ fizichnogo vikhovannia [Determination of HEE students' motives and interests to physical education classes]. Naukovo-pedagogichni problemi fizichnoi kul'turi, 2015;3(57, 15):218 - 222. (in Ukrainian)

9. Mil'ner E. Mozhno li zamenit' beg skakalkoj? [Can run be changed with skipping rope?], Physical Culture and Sport; 2008;12:2-5. (in Russian)

10. Nazarenko LD, Kostiunina LI, Krasnikova NV. Testirovanie urovnia razvitiia ritmichnosti pri zaniatiiakh ozdorovitel'noj aerobikoj [Testing of rhythm level at health related aerobic training]. Teoriia i praktika fizicheskoj kul'tury, 2005;4:57-63. (in Russian)

11. Pravdov MA. Vliianie zaniatij skippingom na fizicheskuiu podgotovlennost' studentov [Influence of rope skipping of students' physical fitness]. Uchenye zapiski universiteta imeni P. F. Lesgafta, 2010;7(65);64-67. (in Russian)

12. Pravdov MA, Korneva MA. Povyshenie effektivnosti zaniatij fizicheskoj kul'turoj so studentami na osnove skipinga [Increasing of physical culture students' training effectiveness on the base of rope skipping]. Mezhdunarodnaia nauchnaia prakticheskaia konferenciia «Razvitie fizicheskoj kul'tury detej $i$ uchashchejsia molodezhi», 2010, Shuya. [International scientific-practical conference "Development of children's and students' physical culture" 2010, Shuya]. 2010. p. 174-176. (in Russian)

13. Red'ko TM. Rozvitok rukhovikh iakostej studentok vishchogo navchal'nogo zakladu zasobami ritmichnoi gimnastiki. Cand. Diss. [Training of HEE girl students' motor skills with means of rhythmic gymnastic. Cand. Diss.]. Chernigiv; 2012. (in Ukrainian)

14. Roters TT. Muzykal'no - ritmicheskoe vospitanie i khudozhestvennaia gimnastika [Musical-rhythmic education and calisthenics]. Moscow: Education; 1989. (in Russian)

15. Sinicia SV, Shesterova LIe. Ozdorovcha aerobika [Health related aerobics], Poltava: PNPU; 2011. (in Ukrainian)

16. Starkova EV. Struktura i soderzhanie modul'noj tekhnologii razvitiia dvigatel'no-koordinacionnykh kachestv $u$ studentok pedagogicheskikh vuzov [Structure and content of module technology of motor skills' training in pedagogic HEEs girl students], Teoriia i praktika fizicheskoj kul'tury, 2009;5:31-36. (in Russian)

17. Krucevich TIu. Teoriia i metodika fizicheskogo vospitaniia [Theory and methodic of physical education], Kiev; 2003. (in Ukrainian)

18. Ter-Avanesian AA. Pedagogicheskie osnovy fizicheskogo vospitaniia [Pedagogic principles of physical education], Moscow: Physical Culture and Sport; 1978. (in Russian)

19. Fanygina OIu. Korrekciia fizicheskoj podgotovlennosti studentok vuzov processe zaniatij ozdorovitel'nymi vidami plavaniia. Cand. Diss. [Correction of HEEs girl students' physical fitness in trainings of health related swimming. Cand. Diss.], Kyiv; 2004. (in Ukrainian)

20. Chernenko OIe. Pidvishchennia fizichnogo stanu studentok $18-19$ rokiv zasobami fitbol-aerobiki. Cand. Diss. [Improvement of 18-19 years old girl students' physical condition by fit-ball - aerobic means. Cand. Diss.], Dnipropetrovs'k; 2012. (in Ukrainian)

21. Beliak YuI, Zinchenko N. Dosing method of physical activity in aerobics classes for students. Physical Education of Students, 2014;5:8-13. http://dx.doi.org/10.15561/20755279.2014.0502

22. Bryukhanova NA, Bulgakova OV, Mokrova TI, Bogashchenko YA. Determination of possibilities of the use of high-intensive trainings facilities on lessons health aerobics. Physical Education of Students, 2013;2:25-29. http://dx.doi.org/10.6084/m9.figshare.156376 
23. Furman YM, Salnikova SV. Improvement of aerobic energy supply processes in 37-49 yrs old women by means of complex aqua-fitness trainings' and methodic of endogenous - hypoxic breathing's application. Pedagogics, psychology, medical-biological problems of physical training and sport. 2015;7:59-63. http://dx.doi.org/10.15561/18189172.2015.0708

24. Kurmaeva EV. Fitness - programs as mean of forming of personality physical culture of students. Physical Education of Students, 2013;1:37-39. http://dx.doi.org/10.6084/m9.figshare.156355

25. Lambourne K, Hansen DM, Szabo AN, Lee J, Herrmann SD, Donnelly JE. Indirect and direct relations between aerobic fitness, physical activity, and academic achievement in elementary school students. Mental Health and Physical Activity. 2013;6(3):165-71.

26. Martyniuk OV. Justification for experimental methods for circuit training aerobics classes first mature age women. Pedagogics, psychology, medical-biological problems of physical training and sports, 2014;11:30-37. http://dx.doi.org/10.15561/18189172.2014.1106

27. Masliak IP. Physical health of young and middle age women under influence of step-aerobics exercises. Pedagogics, psychology, medical-biological problems of physical training and sports. 2015;10:45-50. http://dx.doi.org/10.15561/18189172.2015.1007

28. Pivneva MM, Rumba OG. Aerobics health as means of increasing somatic health of students of special medical group. Pedagogics, psychology, medical-biological problems of physical training and sports, 2013;8:74-87. http://dx.doi.org/10.6084/m9.figshare.747477

29. Pogrebniak IM, Kudelko VE, Nagovitsina OP. Effect of improving aerobics classes at the level of flexibility of female students. Pedagogics, psychology, medical-biological problems of physical training and sports, 2013;5:49_ 52. http://dx.doi.org/10.6084/m9.figshare.707099

30. Pop C, Ciomag V. The Influence of Aerobic Gymnastics on the Students' Body Image. Procedia - Social and Behavioral Sciences. 2014;117:129-35.

31. Rauner RR, Walters RW, Avery M, Wanser TJ. Evidence that Aerobic Fitness Is More Salient than Weight Status in Predicting Standardized Math and Reading Outcomes in Fourth - through Eighth-Grade Students. The Journal of Pediatrics. 2013;163(2):344-8.

32. Solanki R, Bhise A, Shukla Y, Prabhakar M. Effects of high intensity circuit training using body weight on aerobic fitness and muscular endurance in college students. Physiotherapy. 2015;101, Supplement 1:e1418-9.

33. Supilo IP. Biomechanical modeling of the physical training of girls during aerobic activities in non-school educational institutions. Physical Education of Students, 2014;6:73-76. http://dx.doi.org/10.15561/20755279.2014.0614

34. von Haaren B, Haertel S, Stumpp J, Hey S, Ebner-Priemer U. Reduced emotional stress reactivity to a real-life academic examination stressor in students participating in a 20-week aerobic exercise training: A randomised controlled trial using Ambulatory Assessment. Psychology of Sport and Exercise. 2015;20:67-75.

\begin{tabular}{|c|}
\hline Information a \\
\hline $\begin{array}{l}\text { Martinova N. P.; http://orcid.org/0000-0001-8093-7087; } \\
\text { natalya_martinova@mail.ru; Luhansk Taras Shevchenko } \\
\text { National University; Sq. Gogol, 1, of Starobelsk, 92703, } \\
\text { Lugansk region, Ukraine. }\end{array}$ \\
\hline $\begin{array}{l}\text { Cite this article as: Martinova N. P. Results of experimental } \\
\text { testing of hee girl students' motor skills at aerobic trainings. } \\
\text { Physical education of students, 2015;5:46-53. } \\
\text { http://dx.doi.org/10.15561/20755279.2015.0507 }\end{array}$ \\
\hline $\begin{array}{l}\text { The electronic version of this article is the complete one and can be } \\
\text { found online at: http://www.sportpedu.org.ua/html/arhive-e.html }\end{array}$ \\
\hline $\begin{array}{l}\text { This is an Open Access article distributed under the terms of the } \\
\text { Creative Commons Attribution License, which permits unrestricted } \\
\text { use, distribution, and reproduction in any medium, provided the } \\
\text { original } \quad \text { work is } \quad \text { is } \\
\text { (http://creativecommons.org/licenses/by/4.0/deed.en). }\end{array}$ \\
\hline $\begin{array}{l}\text { Received: } 16.08 .2015 \\
\text { Accepted: } 29.08 .2015 \text {; Published: } 02.09 .2015\end{array}$ \\
\hline
\end{tabular}

